\title{
BURGERS IN BRITSE DIENS (1902)
}

\section{Kol Dr Jan Ploeger*}

The article deals with ex-Burghers serving under the British in South Africa during 1902 and their reasons for supporting British Military authorities.

The antagonism between the joiners and the burghers is discussed as well as the joiners' eventual disillusionment with the British government and the contempt with which their fellow countrymen treated them.

In die verlede is hierdie onderwerp reeds dikwels bespreek in woord en geskrif. Die volgende meer resente voorbeelde kan in dié verband genoem word. Allereers die lesing wat V.E. Solomon in November 1972 vir die Suid-Afrikaanse MilitêrHistoriese Genootskap te Johannesburg onder die titel "The Hands-Uppers" gehou het. ${ }^{1}$

In dié lesing dui Solomon o.m. die begin en verdere ontwikkeling aan wat die oorgawe gedagte onder sekere burgers laat posvat het. Hy probeer o.m. peil wat hierdie groep laat besluit het om wapens neer te lê en daarna tot daadwerklike samewerking met die Britse militêre outoriteite oor te gaan en bestee o.m. heelwat aandag aan die National Scouts sowel gedurende as na die oorlog.

In 1979 het A.M. Grundlingh se uiters belangrike studie Die 'Hendsoppers' en 'Joiners' Die Rasionaal en Verskynsel van Verraad, die lig gesien. ${ }^{2}$
Dié wetenskaplike studie sal, wat sy waarde vir die militêre-historikus sowel as die belangstellende leser betref, moeilik verbeter kan word. Die skrywer het ongetwyfeld al die beskikbare gegewens, veral dié wat in ons argiefbewaarplekke berus, uitgeput en nie 'n enkele aspek van sy uitgestrekte studieveld onaangeroer gelaat nie. Ons vestig veral die aandag op die skrywer se uiteensetting van die staatsregtelike posisie van dié burgers wat hulle in Britse oorlogsdiens begewe het soos dit deur die reeds genoemde skrywer, wat ook aandag aan tydgenootlike oorlogsgebruike, soos neergelê in art 44 van die Haagse Konvensie, gewy het. ${ }^{3}$

Grundlingh het verder o.m. verklaar dat daar, volgens die Britse militêre inligtingsdiens, op 1.6.1902 5464 burgers in Britse diens was. ${ }^{4}$

Op 27.4.1902 was die aantal, volgens dieselfde skrywer, $3963 .{ }^{5}$ Deur hierdie totale onder te ver-

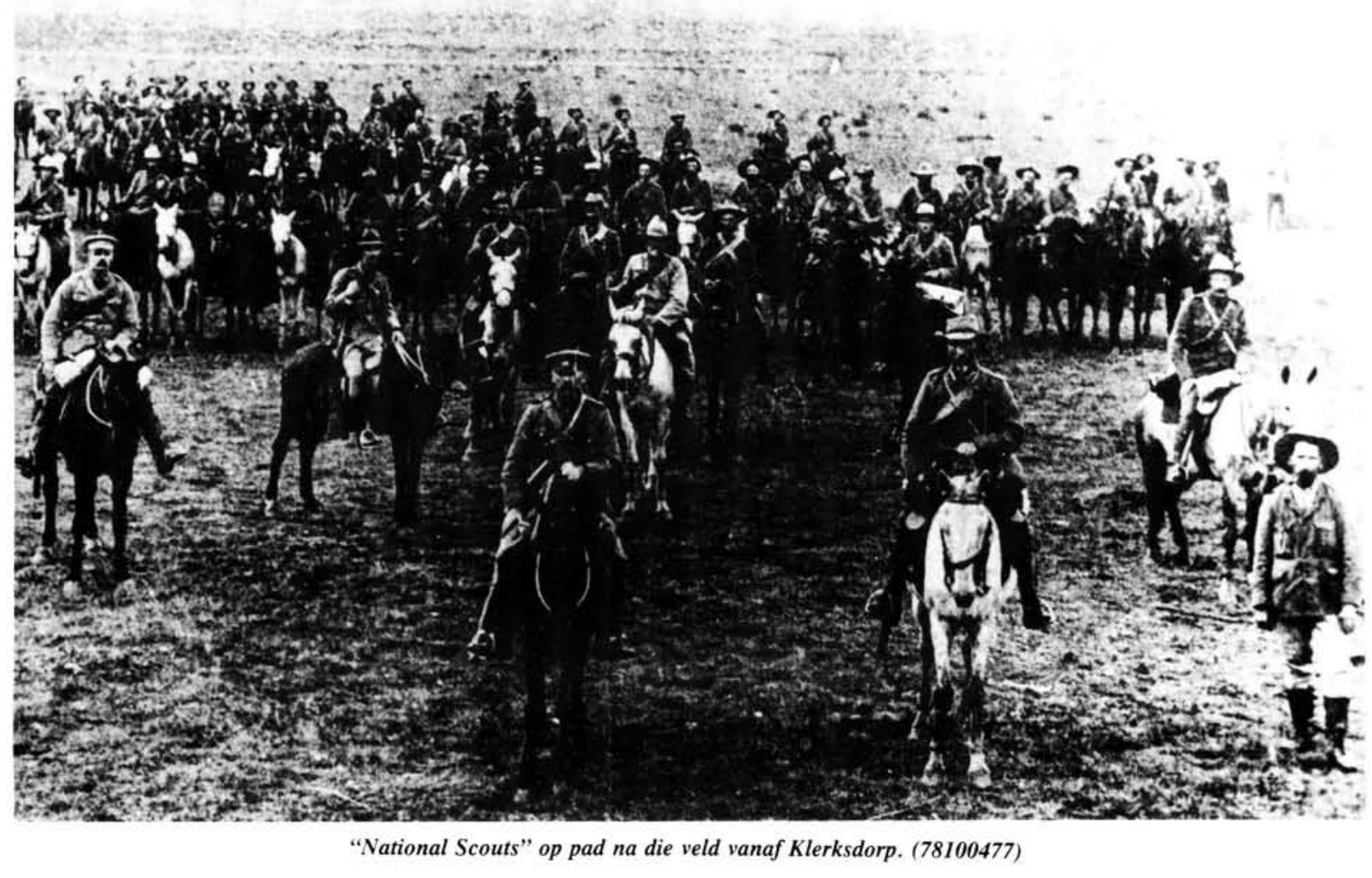


deel in eenhede e.d.m. verkry die leser meer insig in die Britse militêre struktuur sowel as, tot op 'n sekere hoogte, van die soorte van werksaamhede waarmee die burgers in Britse diens belas was.

\section{Die opgaaf van 27.4.1902}

Hierdie opgaaf is, onder die opskrif "The number of ex-Burghers serving under the British in South Africa", deur lt-kol David Henderson en kapt E.H. Stephenson, albei van die Britse Department Military Intelligence, op 1.5.1902 opgestel en bevat die volgende regionale gegewens:

\begin{tabular}{lc}
\hline Dorpe en Gebiede & $\begin{array}{c}\text { Aantal in } \\
\text { Britse } \\
\text { diens }\end{array}$ \\
\hline Kimberley & 66 \\
Mafeking & 159 \\
Noord-Transvaal & 191 \\
Middelburg (Transvaal) & 139 \\
Barberton & 74 \\
Oranjerivierkolonie & 1533 \\
Standerton & 126 \\
Natalse distrikte & 30 \\
Suidwes-Transvaal & 487 \\
National Scouts & 1125 \\
\hline TOTAAL & $3963^{6}$ \\
\hline
\end{tabular}

Uit hierdie syfers kan o.m. afgelei word dat daar meer Transvalers as Vrystaters in Britse diens was, veral wanneer in aanmerking geneem word dat die National Scouts feitlik uitsluitend Transvalers was.

Aan bogenoemde gegewens is, wat eenhede en werksaamhede betref, die volgende onvolledige gegewens toegevoeg:

\begin{tabular}{|lr|}
\hline Eenhede, Werksaamhede: & Aantal in \\
& Britse \\
& diens: \\
\hline Field Intelligence Department & \\
Scouts e.a. & 540 \\
Agente & 27 \\
Tolke & 6 \\
Wadrywers & 318 \\
Imperial Military Railways & $?$ \\
Army Services Corps - Klerke & 5 \\
Native Labour Corps & 8 \\
Lebombo Scouts & 26 \\
Steinacker's Horse & 17 \\
Cattle Rangers & $?$ \\
Militêre telegrafiste & 1 \\
Fighting Burghers & 62 \\
Special Police & $?$ \\
District Mounted Troops & \\
(Mafeking) & 135 \\
Middelburg Guide Corps & 31 \\
Intelligence Burgher Scouts (N & \\
Transvaal) & 133 \\
Assistent -hoofprovooste & 4 \\
Orange River Colony Volunteers & 385 \\
Damant's Horse & 65 \\
Burgher Police & $?$ \\
Town Guards & 130 \\
Ander & 333 \\
Farm Guards & \\
(Oranjerivierkolonie) & 609 \\
\hline
\end{tabular}

Terloops kan hier meegedeel word dat lord Kitchener, vermoedelik aan die begin van Junie 1902, 500 National Scouts in hulle kamp te Pretoria geïnspekteer het. 'n Verslaggewer van The Daily Telegraph het by dié geleentheid opgemerk dat die National Scouts op 'n nuwe wyse gesalueer het. 


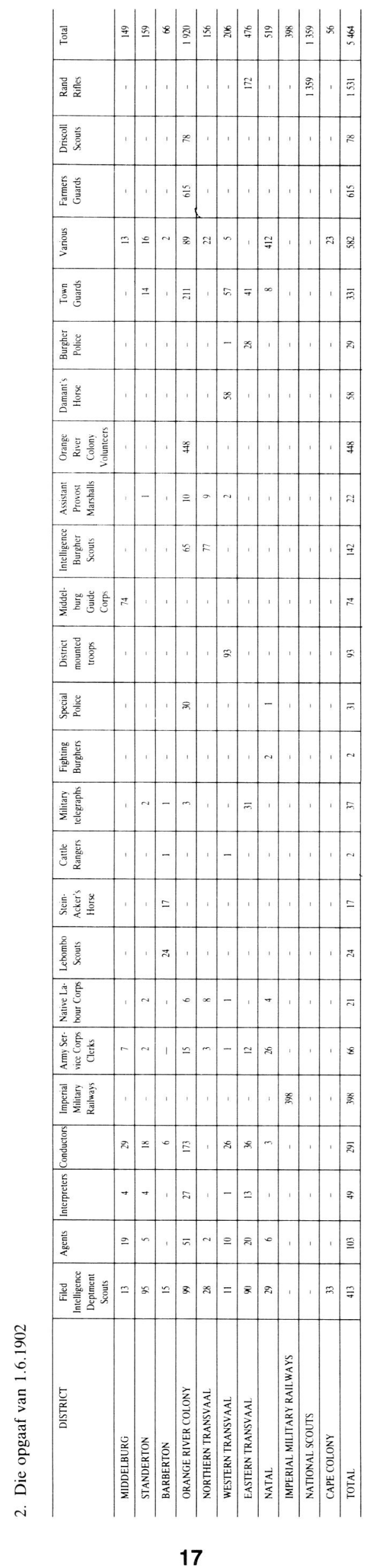


"with their left hands raised to their foreheads, while with their rights they founded their rifles."7

Belangriker as die opgaaf van 27.4.1902 is dié van 1.6.1902 wat hier volledig gepubliseer word. ${ }^{8}$

\section{Die opgaaf van 15.9.1902}

Van September 1902 is daar 'n beknopte verslag van maj E.H.M. Leggett, DSO, RE, die bevelvoerder van die National Scouts, die Orange River Colony Volunteers sowel as van die repatriasie van vrywilligers. Volgens maj Leggett was die sterkte van die genoemde oud-burgers in Britse diens op 15.9.1902 soos volg:

Geattesteerde National Scouts (Transvaal) 1648, Transvaal Intelligence Guides, Scouts en lede van die militêre vervoerdiens - 1400 , geattesteerde Orange River Colony Volunteers - 447, en Orange River Colony Intelligence e.d.m. $1000{ }^{9}$ Hierdie opgaaf stel die aantal oud-burgers, wat op 15.9.1900 nog in Britse diens was, by benadering op 4500 .

\section{Die opgaaf van 26.2 .1903}

Daar bestaan, van die hand van die hoofsuperintendent Vrywilligerrepatriasie, Oranjerivierkolonie, P.H.J. Blakemore, nog 'n verslag van 26.2.1903. ${ }^{10}$ In die verslag is die volgende gerepatrieerdes met hulle werksaamhede genoem:

\begin{tabular}{|c|c|}
\hline $\begin{array}{l}\text { Eenhede of ander } \\
\text { werkgebiede: }\end{array}$ & Gerepatrieerdes: \\
\hline Farmer's Guard & 417 \\
\hline National Scouts & 29 \\
\hline Army Service Corps & 204 \\
\hline Remington's Guides & 7 \\
\hline \multicolumn{2}{|l|}{ Orange River Colony } \\
\hline Volunteers & 361 \\
\hline Field Intelligence Department & 233 \\
\hline Damant's Horse & 37 \\
\hline Driscoll's Scouts & 43 \\
\hline Glen Grey Native Levy & 1 \\
\hline Remount Department & 10 \\
\hline Royal Army Medical Corps & 1 \\
\hline Refugee Camps & 4 \\
\hline Nesbitt's Horse & 4 \\
\hline Field Veterinary Hospital & 6 \\
\hline Town Guards & 51 \\
\hline Scouts & 25 \\
\hline Rand Rifles & 1 \\
\hline \multicolumn{2}{|l|}{ Imperial Military Railway } \\
\hline Volunteers & 3 \\
\hline Kitchener's Fighting Scouts & 12 \\
\hline Guides & 45 \\
\hline Tolk, Claims Board & 1 \\
\hline South African Light Horse & 1 \\
\hline \multicolumn{2}{|l|}{ Thorneycroft's Mounted } \\
\hline Infantry & 4 \\
\hline Burgher Scouts & 27 \\
\hline Kimberley Light Horse & 2 \\
\hline Bergh's Scouts & 33 \\
\hline Ordnance Department & 1 \\
\hline
\end{tabular}

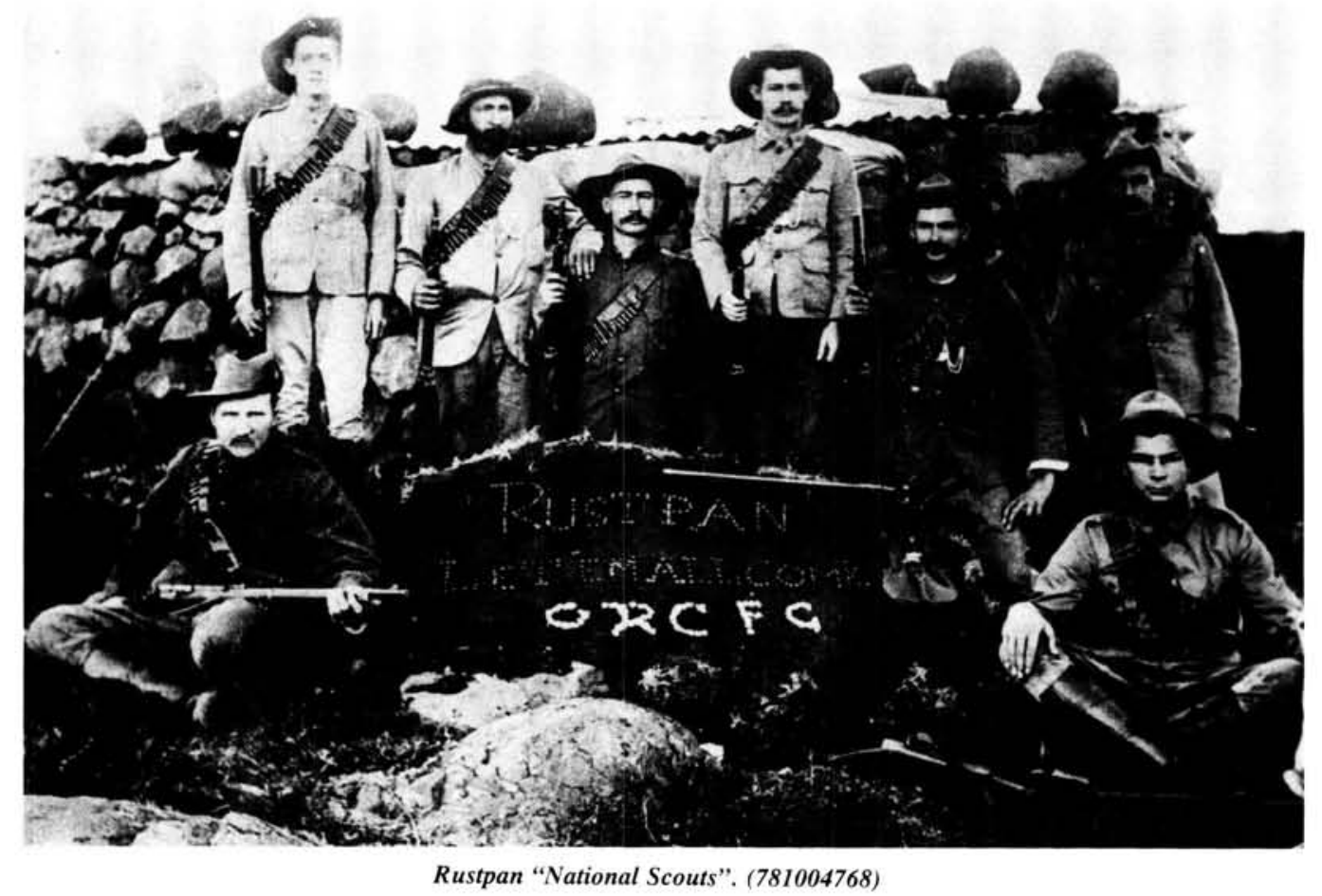




\begin{tabular}{|c|c|}
\hline Brabant's Horse & 1 \\
\hline Military Stock Farms & 3 \\
\hline Imperial Light Horse & 1 \\
\hline Vilonel's Scouts & 7 \\
\hline South African Constabulary & 3 \\
\hline Native Police & 1 \\
\hline Cape Colonial Forces & 3 \\
\hline Orange River Colony Police & 1 \\
\hline Canadian Scouts & 1 \\
\hline TOTAL & 1584 \\
\hline
\end{tabular}

5. Die verspreiding van die gerepatrieerdes in Britse diens in die Oranjerivierkolonie en Transvaal

Aan bogenoemde opgaaf is 'n lys toegevoeg waarin die plekke van herkoms van die 1584 gerepatrieerdes en die bybehorende aantalle oudburgers aangedui is. ${ }^{11}$ Uit die gegewens word die volgende beeld verkry:

\begin{tabular}{|lr|}
\hline Plekke van Herkoms & Aantal \\
\hline Bethlehem & 83 \\
Bethulie & 24 \\
Bloemfontein & 286 \\
Caledonrivier & 13 \\
Fauresmith & 135 \\
Frankfort & 5 \\
Ficksburg & 56 \\
Harrismith & 3 \\
Heilbron & 185 \\
Hoopstad & 18 \\
Heidelberg (Tvl) & 7 \\
Kroonstad & 264 \\
Krugersdorp & 1 \\
Klerksdorp & 1 \\
Ladybrand & 5 \\
Lindley & 13 \\
Moroka & 13 \\
Rouxville & 18 \\
Vrede & 57 \\
Philippolis & 42 \\
Petrusburg & 1 \\
Wepener & 6 \\
Winburg & 299 \\
Senekal & 12 \\
Smaldeel & 1 \\
Smithfield & 4 \\
Ventersburg & 4 \\
Springfontein & 3 \\
Brandfort & 2 \\
Edenburg & 3 \\
Zastron & 1 \\
Vredefort & 9 \\
Boshof & 1 \\
Thaba'Nchu & 2 \\
\hline Totaal & 584 \\
\hline
\end{tabular}

Dit is veral sekere hoë syfers in dorpe soos Bloemfontein maar veral Kroonstad (264), Heilbron (185) en Winburg (299), om selfs 'n paar te noem, wat die belangstellende leser laat nadink. Moet die antwoorde op dergelike vrae gesoek word in die feit dat, om 'n enkele geval te noem, 'n afvallige soos kmdt P.D. de Wet, 'n sterk persoonlike aanhang in Kroonstad en Heilbron geniet het? Hier lê, vir die toekomstige navorser, nog 'n belangrike taak.

\section{Gevoelens. Beloning?}

Grundlingh het 'n belangrike gedeelte van sy werk aan die bestaan van antagonistiese gevoelens tussen die pligsgetroue burgers en die afvalliges, m.a.w. die verraaiers, gewy. Hierdie gevoelens is nie deur die beëindiging van die wapenstryd uitgewis nie. Hierdie aspek, sowel as die beloning vir gelewerde dienste deur die nuwe, naoorlogse owerhede, het o.m. ter sprake gekom aan die begin van 1903. Minister Chamberlain het Suid-Afrika besoek en op 14.1.1903 'n deputasie in die ampswoning van Lord Milner ("Sunnyside"), te Johannesburg te woord gestaan. ${ }^{13}$

Hierdie afvaardiging van "Handsuppers" en "National Scouts", soos hulle in die betrokke dokument genoem is, het bestaan uit:

Genl Andries Cronjé, oud-Volksraadslid W.J. Steyn en 'n sekere Voss (Transvaal); kmdte P.D. de Wet en S.G. Vilonel (Oranjerivierkolonie); ds S.J. du Toit en 'n sekere Snyman (Kaapkolonie). Ds S.J. du Toit het as tolk opgetree.

As eerste spreker het genl Andries Cronjé o.m. verklaar:

"They were the unpopular portion, and they felt that the promises made to them had not been kept.

They were promised that, if they came to the assistance of the Military, all their property, farms, cattle and movables should be protected. This was not done, and in many cases compensation had not been given at all, although perhaps it might be given later. It was represented by some of the Generals that those who took the Oath of Allegiance would become British subjects. At the present time those who had stood out to the last against the British Government were laughing at the men whom he represented. Although the latter felt that they had not had justice done to them, they would neverthe- 


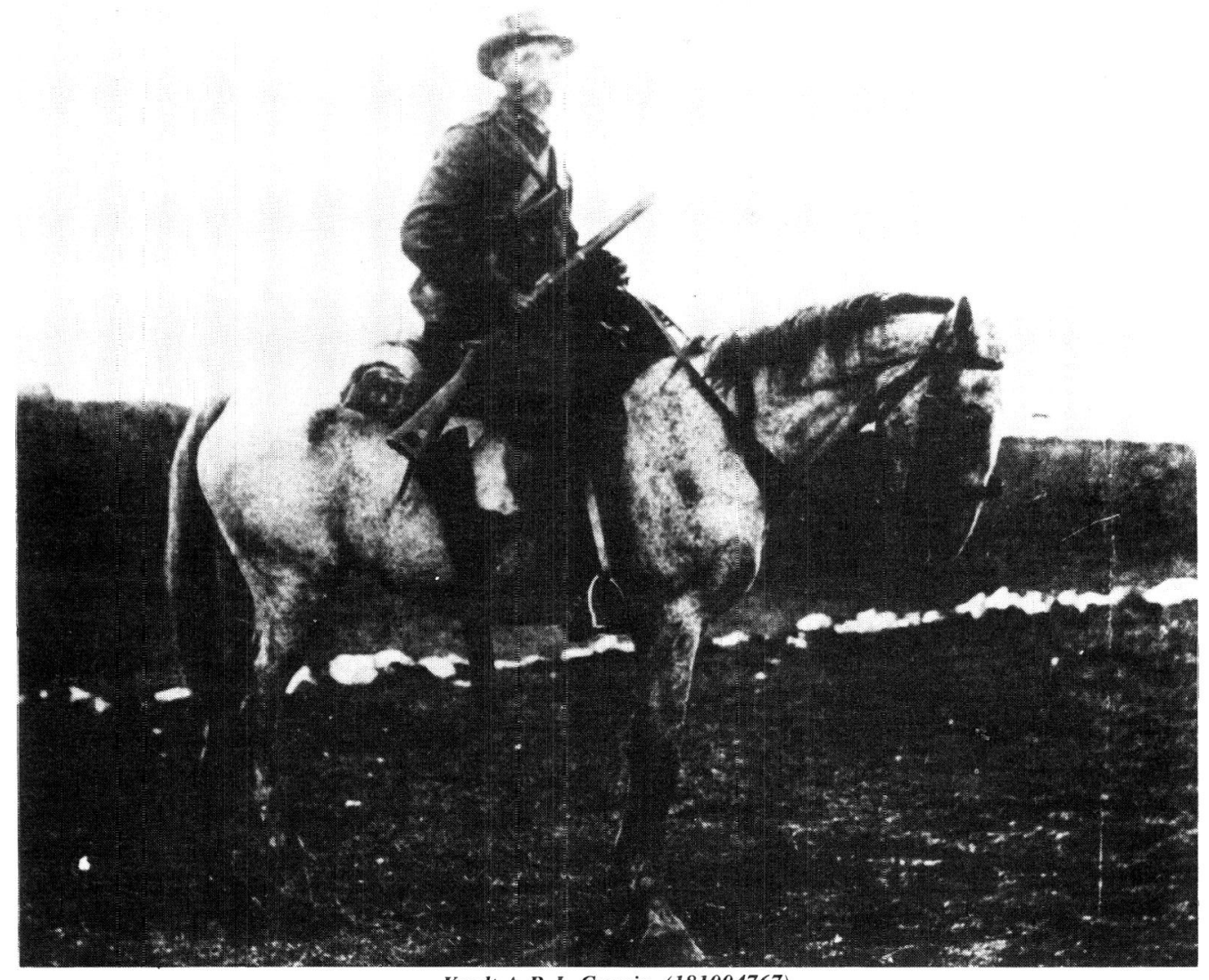

Kmdt A.P.J. Cronje. (181004767)

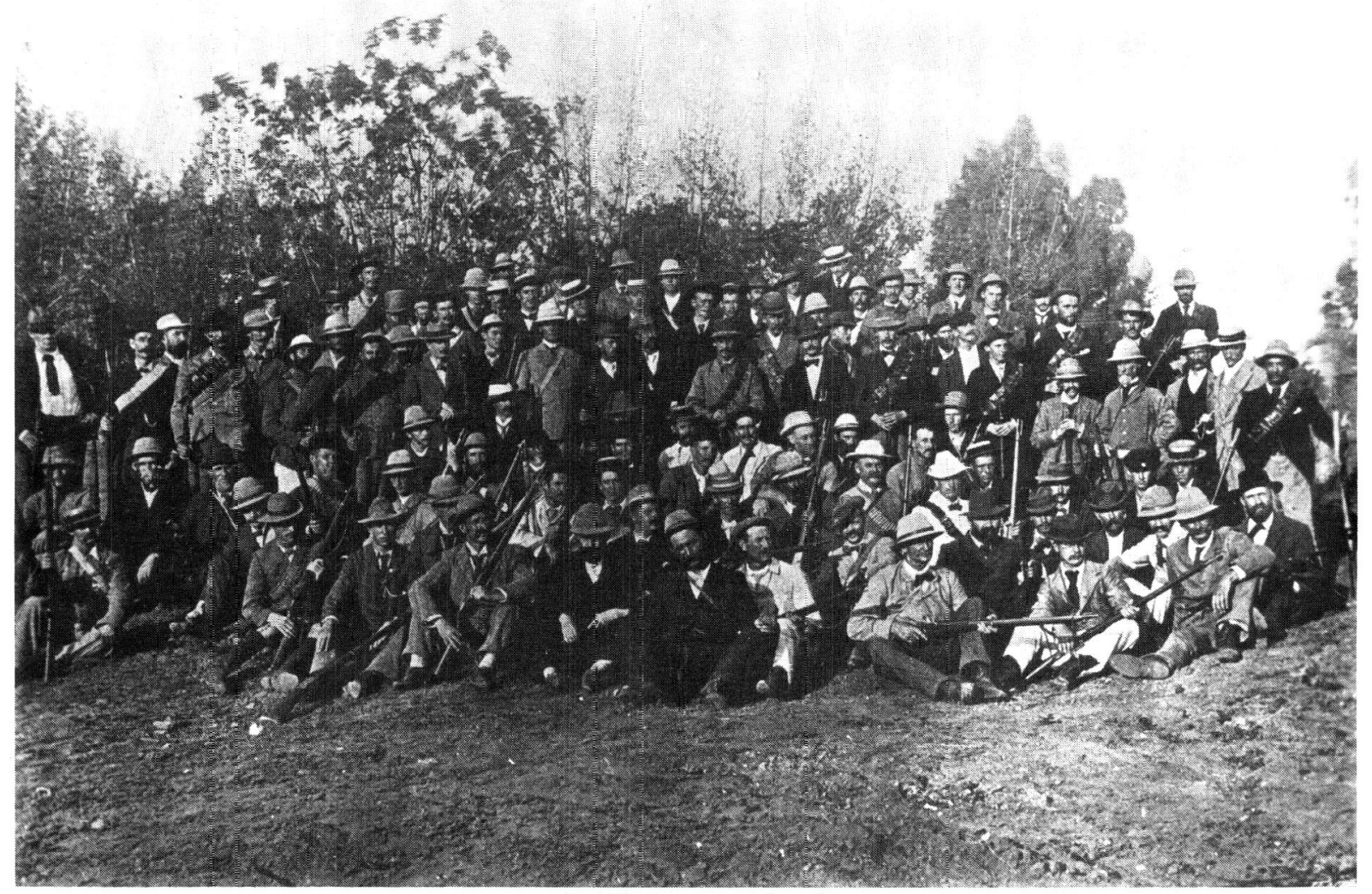

Beleg van Ladysmith. Ladysmith "Civilian Guards" en "Town Guards". (7 1007276) 
less not stand against the Government, but in future they might held aloof.

He complained that the people who had fought to the end did not meet the 'Handsuppers' in the same conciliatory spirit which animated the latter. The only means of conciliation was Land Settlement. There was a large class of poor people, and if they were not provided for in this manner, they would fall under bad influences."

Die volgende Spreker, oud-Volksraadslid Willem Steyn (Standerton), het hom met die vorige spreker vereenselwig. Kmdt P.D. de Wet het o.m. daarop gewys dat hy by die Boereregerings gestaan het solank dié, soos hy dit gestel het, bestaan het.

"Later on when he saw that the war still continued and its useless prolongation would be destructive to the country, he took a lead in the peace movement, but the Boers would not listen and all endeavours to bring about peace failed."

Volgens kmdt P.D. de Wet was daar, as gevolg van die geurilla-oorlog en "their idea ... that had no government", slegs 'n enkele uitweg nl om oor te loop en om, deur die eed van getrouheid af te lê, Britse onderdane te word. Na die oorlog wou hulle versoening bewerkstellig, maar die andersdenkendes wou niks daarvan hoor nie. De Wet het soos volg voortgegaan:

They were branded, distrusted and hated. They had been persecuted even in the Church by their Elders and Ministers. British magnanimity in this country had perhaps gone sometimes too far.

Immediately after the conclusion of the war, the leaders of the late surrenderers were given liberty to go to the Concentration Camps and to address the people; and they were allowed even there to make a distinction between the people and abuse those who had helped the British, if they were not to lose influence, should be rehabilitated by the action of the Government."

In sy verdere betoog het kmdt De Wet die Britse Minister van Kolonies (Chamberlain) duidelik laat verstaan dat hy en sy geesverwante, op grond van hulle werk en Britse beloftes meer vergoeding verwag het as die bittereinders.

"With them it was a question of principle

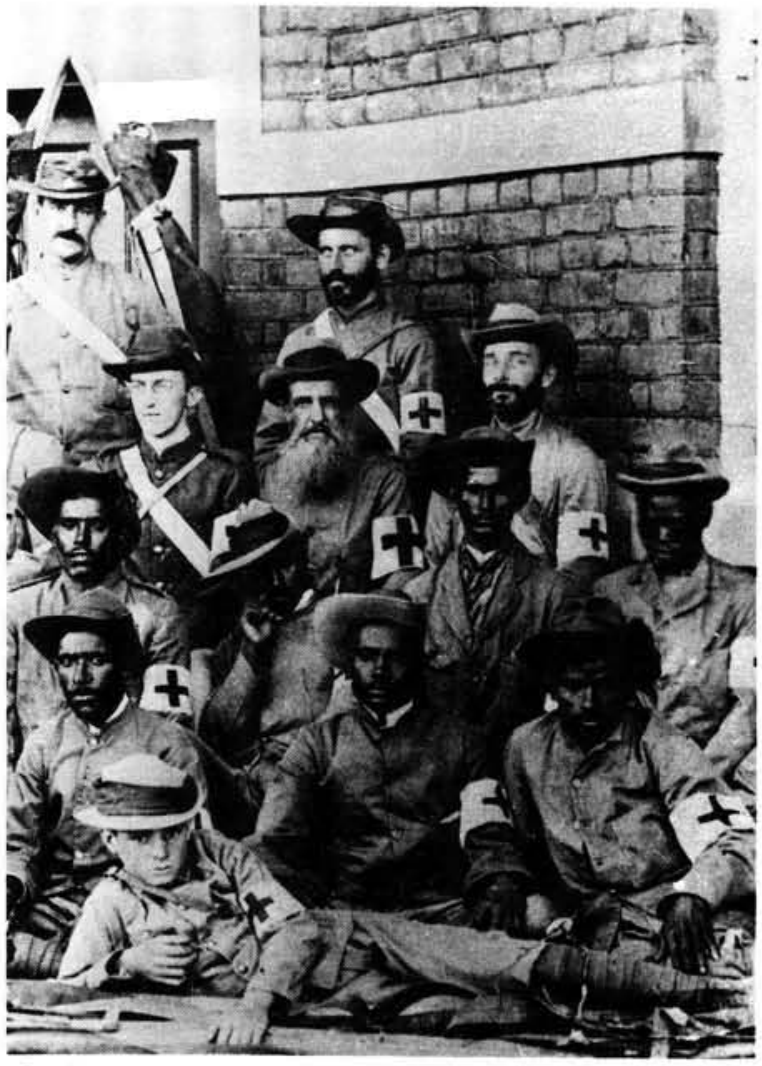

Rooikruisafdeling van Cradock. "Town Guards". (77100077)

rather than of money. What they claimed from the British Government was a claim of right and justice and not of gratuity and of grace. They had a moral claim which the other party had not. Yet the other party now came to them and said we had to make terms for you. We had to get the three millions for you. You would have had nothing if it had not been for us."

Kmdt De Wet het, in hierdie verband, verwys na artikel 10 oor skadevergoeding, soos opgeneem in die ooreenkoms wat die oorlog op 31.5.1902 beeindig het.

Die laaste spreker, kmdt Vilonel, het kmdt De Wet se argumente herhaal en daaraan toegevoeg:

"Repatriation Boards were constituted rather to suit the men who had stayed out to the last than those who had thrown in their lot with the British."

In sy repliek het minister Chamberlains geantwoord dat die sprekers en hulle geesverwante hulle uiteindelik in 'n beter posisie sou bevind, dat Brittanje dankbaar teenoor sy vriende is, dié vriende nie sal vergeet nie en sy bes sal doen om hulle, net soos die bywoners, te help. 
Op die lange duur het die vertoë van Suid-Afrikaners wat in die Tweede Vryheidsoorlog lojaal teenoor Brittanje was, niks opgelewer nie. Hierdie mense (en veral diegene wat as Transvaalse en Vrystaatse burgers na die vyand oorgestap het) se hoë verwagtinge oor materiële gewin as vergoeding vir hul dienste aan die Britse bewind, het op ydele hoop berus: die oorwinnaar, pynlik bewus van die groep se onsekere aansien in 'n gemeenskap wat reeds na politieke ontvoogding gemik het, was allermins begerig om verhoudinge met politieke leiers te vertroebel. Hulle was 'n geïsoleerde groep wat eweneens in die aangesig van 'n nuwe nasionalisme min simpatie gekry het. Ná Uniewording is dié 'lojale' groep in die kloof tussen Afrikaans- en Engelssprekendes nog verder verguis. As Brittanje hulle dan vergeet het, kon hul volksgenote nie vergeet nie, dog in 'n ander sin: mense wat in die volksoog as verraaiers en 'hensoppers' gebrandmerk is, word nooit vergeet nie.

- kol dr Jan Ploeger is Staatshistorikus verbonde aan die staatsargief. Pretoria.

Bronnelys

1. Military History Journal Krvgshistoriese Tydskrif, deel 3. nr 1. Junie 1974 (Johannesburg, 1974).

2. Pretoria - Kaapstad. 1979

3. A.M. Grundlingh, t.a.p.. p. 167 e.v.

4. Ibid., p. 167.

5. Ibid.

6. TAB. FK 1202. Milner Papers 113, 1.5.1902.

7. Ibid., Aanwins A1016. The Daily Telegraph (ongedateerde knipsels). Die parade en inspeksie is kort na 31.5 .1902 gehou.

8. Ibid., FK 665. CO 26810. Return of Ex-Burghers serving under British for week ending 1st June 1902

9. TAB OVS 165, Intermediate Report of Re-Settlement National Scouts, ORC Volunteers and Ex-Military Burghers (Confidential). 15.9.1902. p. 12.

10. Cd 1551.pp. 61-62.

11. Ibid., pp. $62-63$.

12. Die volgende besonderhede is ontleen aan TAB. FK 1207. Milner Papers 118 (notule). 14.1.1903,

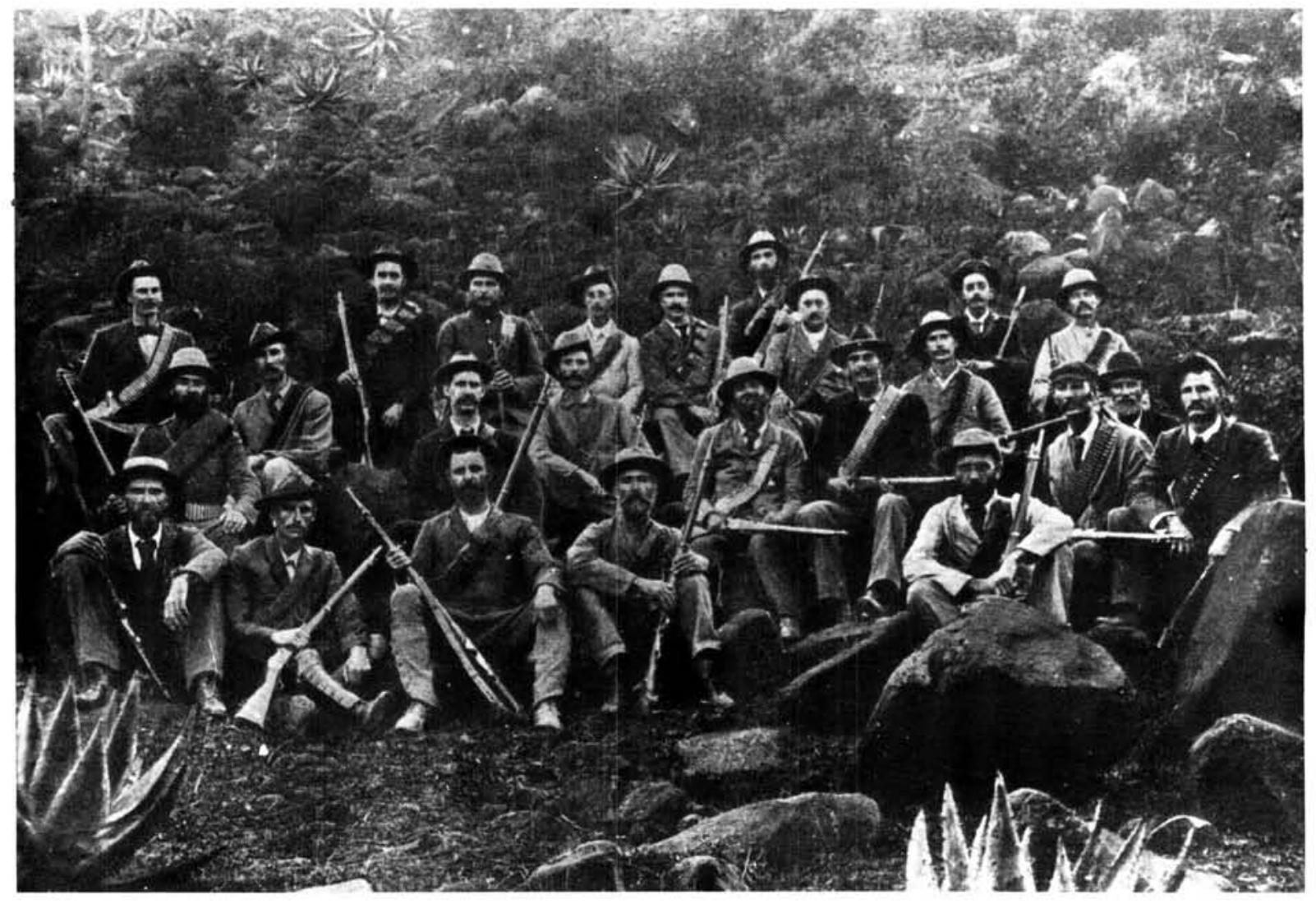

Kliprivier Skietvereniging, lede van die "Town Guard" van Ladysmith. (761007278) 